OPEN ACCESS

Edited by: Simon Jungblut,

University of Bremen, Germany

Reviewed by:

Magdalena N. Georgieva Natural History Museum,

United Kingdom

Lisa Mevenkamp

BioConsult Schuchardt \& Scholle

GbR, Germany

*Correspondence:

Eva Paulus

eva.paulus@outlook.com

Specialty section:

This article was submitted to Global Change and the Future Ocean,

a section of the journa

Frontiers in Marine Science

Received: 11 February 2021

Accepted: 04 March 2021

Published: 06 April 2021

Citation:

Paulus E (2021) Shedding Light on Deep-Sea Biodiversity - A Highly

Vulnerable Habitat in the Face of Anthropogenic Change.

Front. Mar. Sci. 8:667048.

doi: 10.3389/fmars.2021.667048

\section{Shedding Light on Deep-Sea Biodiversity-A Highly Vulnerable Habitat in the Face of Anthropogenic Change}

\author{
Eva Paulus* \\ University of Groningen, Groningen, Netherlands
}

The deep sea is the most extensive habitat on our planet, and it supports surprisingly high biodiversity. With a multitude of different environments and conditions previously thought to be inhabitable, it is unclear how such high diversity was able to develop, but habitat heterogeneity and nutrient flux are certainly important factors to consider. In this review, the different methodologies used to examine biodiversity in the remote depths of the oceans are considered. In addition, the different environments in which biodiversity is studied are presented, and the various hypotheses on how high biodiversity is possible are examined. Unfortunately, this diversity is threatened by human impact similarly to shallow waters, and future endeavors such as deep-sea mineral extraction must be considered as a major threat to the environment. Many mysteries persist in the deep sea, but it is certain that threats such as overfishing, plastic pollution, and changes in ocean chemistry due to climate change are impacting even the most remote places in the oceans. It remains uncertain whether the deep sea is resilient toward anthropogenic disturbances, yet this is difficult to research on short timescales. There is little hope for areas in which exploitation, such as deep-sea mining, will be directly impacting the benthos and proper regulations are required to preserve biodiversity in the deep sea.

Keywords: biodiversity, deep-sea environment, anthropogenic threats, climate change, deep-sea mining, deep sea

\section{INTRODUCTION}

\section{Biodiversity and Resilience}

Biodiversity describes the variety of organisms living in a certain habitat and can be analyzed within and between species. Using genetics and taxonomy, diversity can be measured between individuals and their populations, which can provide important information on, for example, life history stages and migration. Generally, higher genetic diversity in a population is beneficial, as populations are able to withstand a broader range of environmental conditions and are more resilient to changes within ecosystems (Gray, 1997; Des Roches et al., 2018). In the marine realm, there are a several hotspots of biodiversity that are widely accepted, such as mangrove forests or coral reefs. A more surprising habitat that is highly diverse is the deep sea, upon which this review will focus.

Mora et al. (2011) estimated the number of species found in the oceans to be around 2.2 million, with over $90 \%$ still undescribed. The increasing threats to our oceans, however, are likely to drive 
many species to extinction before we can catalog them and learn about their habits, life cycle and, most importantly, their role in the ecosystem.

Species accumulation curves allow the number of species still to be discovered in a certain habitat to be estimated, using the number of species of a certain phylum or group described over the last centuries (Bebber et al., 2007; Mora et al., 2008). When this curve flattens for considerable periods of time, it suggests that a high percentage of species in the habitat or level of biological organization have been found. Accumulation curves can also be constructed for samples in a certain habitat after examining a certain number of samples, as shown in Figure 1. Unfortunately, taxonomic studies are difficult to fund and experts are crucial in identifying organisms to species level, which in turn means that fewer species are being described currently. A renewed interest and more funding availability would help to fill the gaps in our knowledge toward the very fundamentals of life on Earth (Mora et al., 2011). To aid this search and catalog biodiversity, genetic analyses are of high importance, and the development of cheaper and faster sequencing methods is a great advantage.

Biodiversity is a factor in another concept that is highly debated-resilience. There are two general notions of resilience, namely engineering and ecological resilience. The major difference in viewpoint is that in engineering resilience, an ecosystem is assumed to have only one equilibrium point that it will return to after a disturbance (Holling, 1996). In contrast, ecological resilience acknowledges that there may be multiple steady-states in a system when conditions change, and the difficulty of returning to the original state may be unachievable if the disturbance is too large (Gunderson, 2002). In the context of our oceans, such disturbances can be temporary, such as oil spills, dredging operations, or algal blooms due to mismanaged waste waters. Examples of long-term disturbances are the rise in ocean temperatures or ocean acidification (National Research Council, 2013). In engineering resilience, the important factor considered is time-the time it takes for the ecosystem to return to its original state. On the other hand, ecological resilience focuses on the amount of stresses and disturbances an ecosystem can absorb before entering and rebalancing to a new stable state (Gunderson, 2002). Considering the strong anthropogenic influence on the entire planet, conservationists aim to preserve the preindustrial state of ecosystems wherever possible. Therefore, this review will focus on the ecological resilience viewpoint. Biodiversity is a key component of resilience, especially longterm resilience that aids the preservation of ecosystem functions and services (Oliver et al., 2015). Biodiversity is especially important to upkeep the structure and performance of different ecosystems within functional nodes, such as trophic levels (Steneck et al., 2002).

Humans have a history of introducing extinction and immense biodiversity loss upon their arrival to new landmasses. Human impact has often been the main culprit when animals have faced extinction in the recent past, including impacts such as rapid overharvesting or habitat loss (Burney and Flannery, 2005). Megafaunal extinctions seem to coincide with the arrival of aboriginal humans to an ecosystem (Lyons et al., 2004; Sandom et al., 2014). This phenomenon is now exacerbated by the consequences of modern technologies and fossil fuel burning, i.e., climate change - the current rate of biodiversity loss far exceeds the normal rate (Brondizio et al., 2019). In mammals, Ceballos et al. (2015) found that the current rate of extinction-the "sixth mass extinction"-is up to 100 times higher than during previous extinctions. Cooke et al. (2019) modeled predicted extinction losses of birds and mammals and found that small, transient, highly fecund generalists are best suited for the threats they are likely to face within the next century. However, studies are largely biased around celebrity species where a decline is immediately noticeable. In smaller, lesser-known species and groups such as invertebrates, a drop in population numbers is less newsworthy and, therefore, not regarded as equally important by the general public (Régnier et al., 2015). In addition, it is impossible to gauge the decline or extinction of a certain species without having reliable baseline data, which is often not available.

An environment where pre-industrialization baseline data are completely missing is the deep sea. It is a largely unexplored habitat with high biodiversity and a critical need to assess resilience on a larger scale. Similar to the shallow waters, the deep sea is threatened by anthropogenic disturbance, with new and direct threats from mineral mining increasing with technological advances. Scientists are racing to catalog species and their habitats to form a baseline against future impacts such as climate change, and to preserve the knowledge hidden in the depths of the ocean before it is extinguished.

\section{Characterization of the Deep-Sea Environment}

Generally, everything below $200 \mathrm{~m}$ is considered to be deep sea, where light becomes scarce and primary production is restricted (Ramirez-Llodra et al., 2010). About 50\% of the surface of the Earth is ocean deeper than 3,000 m (Ramirez-Llodra and Billet, 2006). It is, therefore, worth considering that the deep sea is not in fact an unusual habitat-it is the norm, while land-based habitats are quite rare in comparison.

Long regarded as a vast, desert-like ecosystem, devoid of life with conditions too extreme for life to thrive, the deep sea was not considered important. Forbes noticed during an expedition in the mid-nineteenth century that the number of species declined with increasing depth and hypothesized that life below $550 \mathrm{~m}$ depth is likely to be extinguished, which is now known as Forbes' azoic hypothesis (Anderson and Rice, 2006). Until the 1860s, this was the prevailing belief, when expeditions were undertaken that would change the view of the deep sea forever-these included the two deep-sea research expeditions, the HMS Lightning and HMS Porcupine between 1869 and 1870 (Gage and Tyler, 1992). Most famously when the HMS Challenger circumnavigated the world between 1872 and 1876, the diversity of deep-sea life was uncovered (Roberts, 2002).

These expeditions showed that not only is there life in the deep sea, the environmental conditions produce quite unique and highly adapted animals. It has since been attempted to study this habitat in detail, and while efforts are ongoing, it is an exceedingly difficult task, as the area is immense, difficult to access, and, thus, researching it is very expensive. 


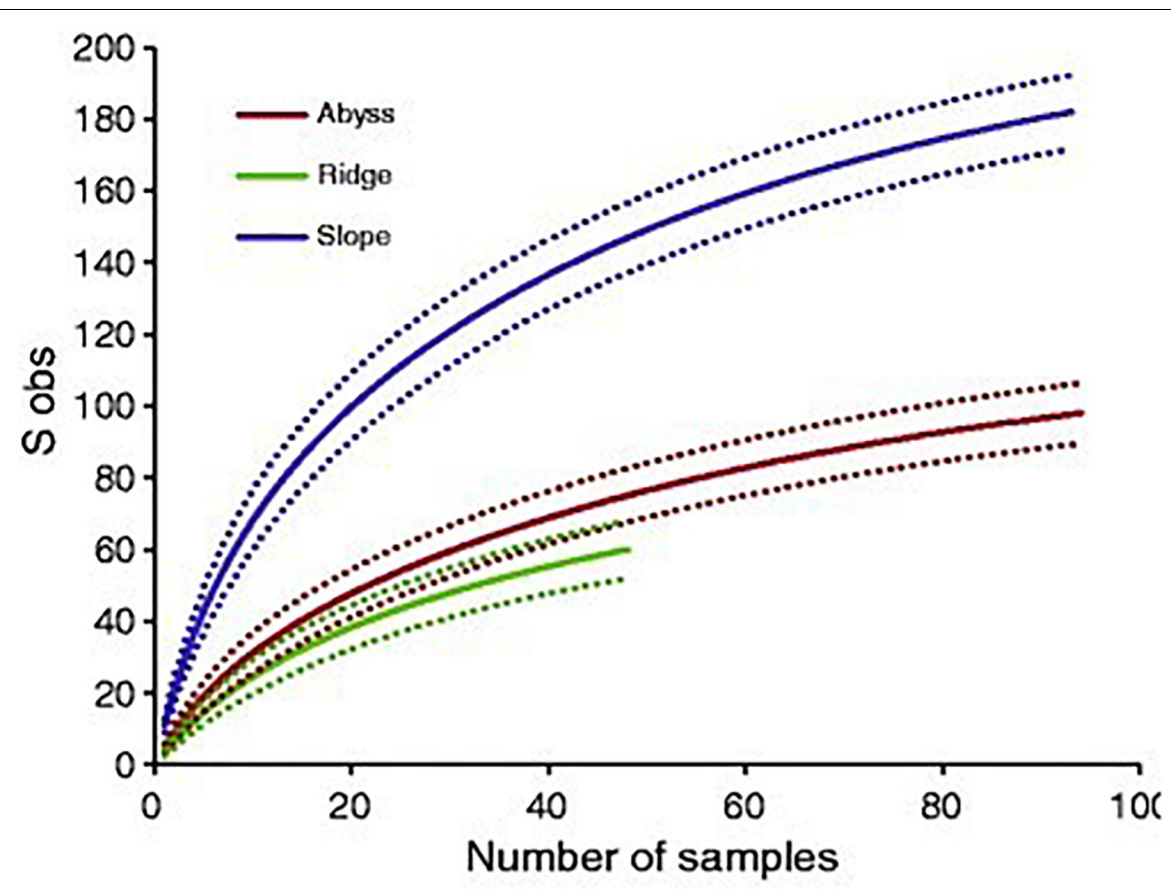

FIGURE 1 | A species accumulation curve for arctic deep-sea polychaetes found at slopes, ridges and abyssal stations (reproduced from Bodil et al., 2011, which is distributed under the terms of the Creative Commons Attribution Non-commercial License).

The conditions commonly encountered in the deep sea are high pressure, low temperatures, and intense darkness (Gage and Tyler, 1992). Species living in this environment are adapted to the challenges-for example, biochemical difficulties due to the pressure and low temperatures are compensated by changes in enzyme structures (Brown and Thatje, 2014). Nevertheless, these pressure-insensitive enzymes are slower, which affects the metabolism of the animals (Thistle, 2003). A slower metabolism can create problems when external disturbances, such as those arising from human impact, are causing changes in the environment (Danovaro et al., 2017). Except for hydrothermal vent and cold seep communities, where chemosynthesis fuels primary production, the organisms found in the deep sea are food-limited and productivity is low.

Genetic analyses suggest that the deep sea habitat shares many biological characteristics with better studied environments, for example rates of speciation on a species and genus level are similar to less extreme environments (Creasey and Rogers, 2008). Similarly, they may be affected equally by anthropogenic impacts, such as ocean acidification and warming (Turley et al., 2007; Kirkman and Bitz, 2011). In addition, the different environments in the deep sea have similar functions to shallow water environments. For instance, deep-sea corals are a nursery ground for fish larvae and provide an important safe harbor for different species similarly to tropical shallow-water coral reefs (Baillon et al., 2012).

Phytodetritus is the major food source for animals living in the deep sea-it is dependent on photosynthetic primary productivity occurring in the surface layer and sunlight (Fisher et al., 2016). Hydrothermal vents, on the other hand, are a unique habitat as the animals living there do not depend photosynthesis for their nutrition - they are chemoautotrophic (Ramirez-Llodra and Billet, 2006). Chemosynthesis only signifies about 0.02$0.03 \%$ of total annual oceanic production of organic carbon (van Dover, 2000).

The deep sea is largely unexplored, and many questions remain. It is currently undergoing exploitation and there are plans to do so even more in the future. Due to a lack of long-term data, changes within the ecosystem are nearly impossible to determine (Fisher et al., 2016). In light of the many unknowns, it is advisable that the precautionary principle will be applied when managing human activity in the deep ocean and strict rules will be imposed on any undertakings that impact these areas.

\section{VARYING ENVIRONMENTS FOUND IN THE DEPTHS OF THE OCEAN}

There are a multitude of different environments in the deep sea, of which the most relevant are mentioned here. In general, the oceans are divided into different zones based on depth. The sunlight photic zone at the surface is followed by the mesopelagic zone between 200 and $1,000 \mathrm{~m}$. The bathypelagic zone is found between 1,000 and $2,000 \mathrm{~m}$, while the abyssopelagic and hadopelagic are even deeper (Costello and Breyer, 2017).

The most common habitat is the abyssal plain, exhibiting low overall biomass and high species diversity (Durden et al., 2015). Abyssal plains cover over $50 \%$ of the earth's surface and 
are defined as ocean floor between 3,000 and 6,000 m (Smith et al., 2008). The physical conditions are stagnant-slow currents and cold temperatures are the norm (between -0.5 and $3^{\circ} \mathrm{C}$ ) (Smith et al., 2008). In addition, the sediment is mostly biogenic, and the environment is food-limited as the primary source of energy is marine snow, detritus slowly raining down from waters above (Smith and Demopoulos, 2003). In general, no primary production takes place and the environment is food-limited (Iken et al., 2001).

Phytodetritus was assumed to be in constant supply in the deep sea, not adhering to seasonal changes-this was only disproven in the 1980s through the use of time-lapse cameras: Lampitt (1985) found extremely fast accumulation of organic material coinciding with spring blooms, with a sinking rate of about $100 \mathrm{~m}$ per day in the northeastern Atlantic $\left(50^{\circ} \mathrm{N}\right)$. Within a few days, the environmental conditions in the deep sea are altered dramatically, even to a depth of $4,100 \mathrm{~m}$ (Lampitt, 1985). Detrital aggregates ("clumps") can form on the sea floor (Lauerman and Kaufmann, 1998). Biodiversity increases noticeably (Lambshead et al., 2002) in an instantaneous response-opportunistic species are able to proliferate which can have lasting effects on other species in the ecosystem (Gooday, 1988).

Hydrothermal vent fields are found in regions where water is able to penetrate deep into the Earth's crust, such as in areas where tectonic plates are moving apart. Superheated water is ejected that enables the creation of a unique ecosystem based around chemosynthesis, and with it an environment not dependent upon sunlight. High endemism in hydrothermal vent communities is the norm (Price, 2002), with more than 500 hydrothermal vent species identified at the moment (Desbruyères et al., 2006). Since hydrothermal vents were discovered in 1977, research has focused in a narrow corridor around the ridges, until the Lost City hydrothermal vent field was discovered $15 \mathrm{~km}$ from the spreading axis of the Mid-Atlantic Ridge in the year 2000 (Kelley et al., 2005). While the commonly described hydrothermal vent fields are found at the center of tectonic spreading centers and can eject water at up to $400^{\circ} \mathrm{C}$, the Lost City vents are found further away and are connected to older tectonic crusts, with water expelled at around $40-75^{\circ} \mathrm{C}$ (Kelley et al., 2001). Interestingly, macrofauna abundance at the Lost City vent was especially low, while microbial communities flourished (Kelley et al., 2001). These findings suggest that there are more unique hydrothermally active habitats in the deep sea that are just waiting to be discovered, and more research should focus on the surroundings of the already discovered hydrothermal vent fields. The discovery of new habitats surrounding hydrothermal vents is also increasingly interesting from a resilience standpoint-shared species may be able to migrate between ecosystems and aid recovery (Gollner et al., 2015).

Continental margins are areas between the continental shelf and the deep ocean basin (Figure 2). The terrain is extremely variable and a multitude of factors influence it as a habitat, such as tectonic activity, mud slides, or debris from river outflow (Levin et al., 2010). This high habitat heterogeneity is known to affect biodiversity positively (Levin et al., 2010; Levin and Sibuet, 2011), making continental margins an interesting study ground for biodiversity research.

Another common deep-sea environment are seamountsvolcanic structures that rise from the ocean floor and exhibit a diverse habitat and unique oceanographic features (Figure 2).

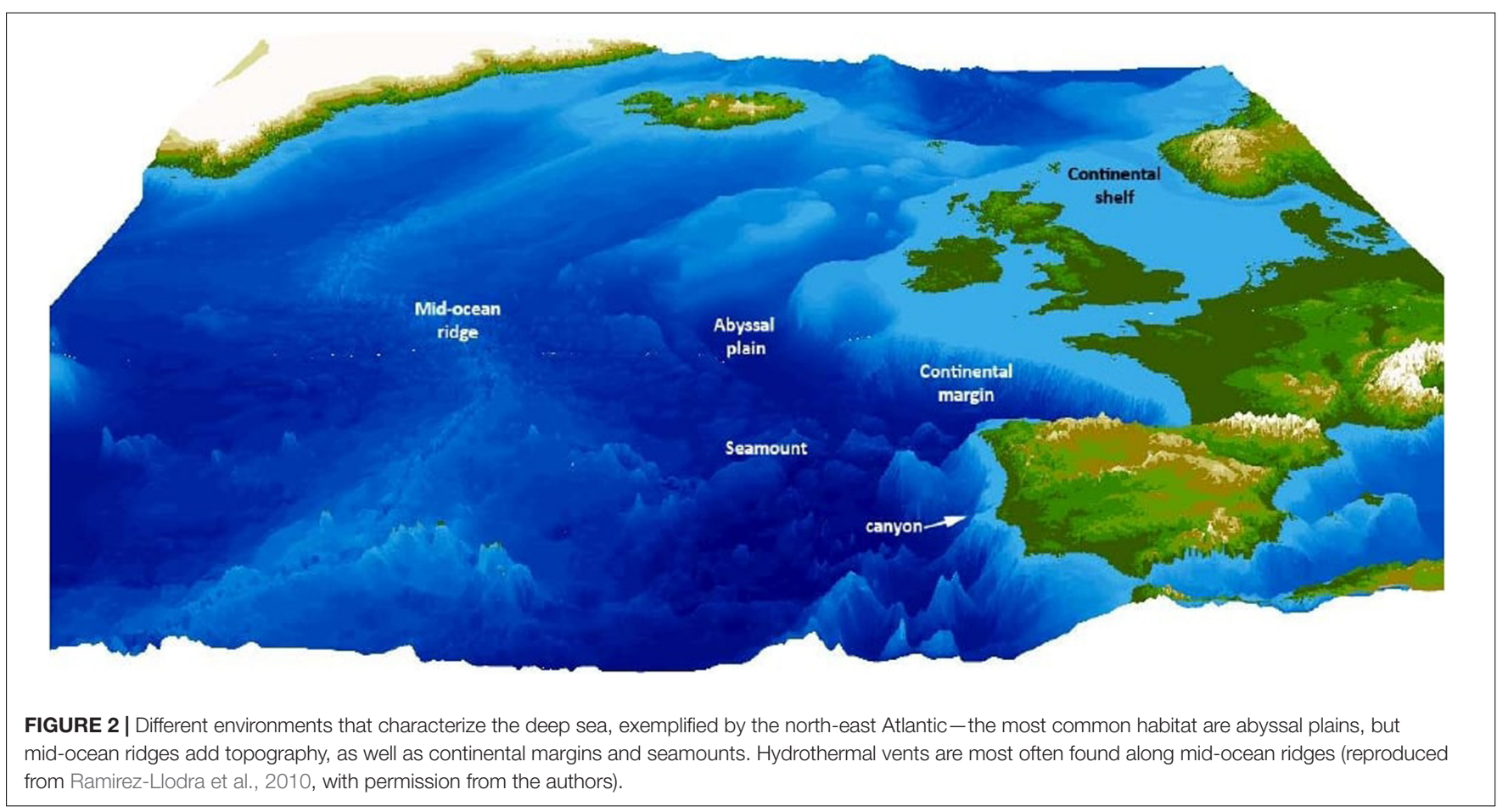


Similarly to hydrothermal vents, they are often formed close to the mid-ocean ridges and are geologically very young (Pitcher et al., 2007). In addition, they are found in hotspots associated with continental plates, and around island arcs (Yesson et al., 2011). Strong upwelling and hydrodynamics create unique ecosystems with low sedimentation and an abundance of benthic filter-feeding fauna (Boehlert and Genin, 2013). Seamounts host a diverse assemblage of flora and fauna, from deep-sea corals, fishes, cephalopods to turtles and even marine mammals (Stocks and Hart, 2007). Biodiversity at seamounts is high (Morato et al., 2010), and seamounts are potentially important in fostering speciation in the deep sea (Pitcher et al., 2007). Complex geomorphic features may be of high importance for biodiversity in the deep sea, exemplary shown by cold-water corals found on vertical walls in the deep sea, as they cannot be trawled on and likely remain relatively untouched from human disturbance (Robert et al., 2019).

On a much smaller scale, cold water corals can build mounds in the deep sea that form unique habitats as well (Soetaert et al., 2016). As ecosystem engineers, corals slowly deposit their skeletons on the seafloor, which in turn traps sediments and builds up larger reef structures (Roberts et al., 2006). These formations are then potentially able to induce downwelling to pump organic matter from the surface to the mounds to increase food supply (Soetaert et al., 2016).

The hadal zone extends below $6,000 \mathrm{~m}$ to the deepest points on earth (Jamieson et al., 2010). Few fish species are able to live deeper than $8,000 \mathrm{~m}$, notably the snailfishes (Scorpaeniformes) from the Mariana trench are reported to be thriving at those depths (Gerringer et al., 2017). This limitation may be due to the hydrostatic pressure which restricts the production of proteins necessary to sustain vertebrate life and form tissues (Yancey et al., 2014) - nevertheless, other animals are found even deeper than 8,000 m. Amphipods have been found in samples from 8,074 $\mathrm{m}$ in the Peru-Chile Trench, however, in lower abundances as depth increased (Fujii et al., 2013). In addition, bivalves, isopods, holothurians, polychaetes, and gastropods are also reported in the hadal zone (Jamieson et al., 2010). While data is scarce on the abundance and species composition at such great depths, ecosystem heterogeneity seems to be the deciding factor that influences community structure in these depths (Lacey et al., 2016).

Oxygen minimum zones (OMZs) are regions where oxygen concentrations are extremely low (most often described as $\mathrm{O}_{2}<20 \mu \mathrm{M}$ ) (Paulmier and Ruiz-Pino, 2009). Due to surface primary productivity and oceanographic phenomena such as stratification, these zones are created and cause a low-oxygen environment for the associated fauna (Gooday et al., 2010). Nevertheless, there are organisms highly adapted to OMZs that are able to, for example, increase surface area for more efficient oxygen uptake, such as larger gills, smaller body size or increased station (Gooday et al., 2010). Rogers (2000) even hypothesized that physical changes in the environment, such as low oxygen conditions, contribute significantly to higher species diversity, especially on a regional scale as allopatric specialization and speciation may be high. In general, abundance of all animal groups is reduced in an OMZ core region. Some animals can cope with low-oxygen conditions better, such as foraminifera, while megafaunal invertebrates and macrofauna were found to be almost completely absent in the OMZ core on the Pakistan margin (Gooday et al., 2009).

\section{METHODS TO ASSESS DEEP-SEA BIODIVERSITY}

Sampling in the deep sea to assess biodiversity is analogous to sampling the Amazon rainforest from a helicopter-it is very difficult to obtain quantitative and representative samples. We can only assess small parts of the ocean floor, e.g., using box corers or video systems, and it cannot be said with certainty that the samples obtained are representative of the larger area.

There are a few different methodologies to evaluate the biodiversity of deep-sea organisms. Some include catching the organisms directly, others use camera systems to assess species composition. None of the methods are flawless and the best approach would certainly be to combine multiple, which is often challenging due to the cost of ship time and chartering the equipment. Figure 3 shows the equipment used by the RV Pelagia to sample the oceans, showcasing the immense technological necessities to gain knowledge about the ocean floor.

At the moment, the most widespread method to sample zooplankton in the deep sea is simply using nets, which can be towed horizontally or vertically, depending on the environment and the research question (Christiansen, 2016). To differentiate between the depths at which the specimens were collected, nets were developed that can be opened and closed remotely while sampling. This gives a much better resolution of habitat specificity and, especially important in zooplankton, daily vertical migration patterns (Christiansen, 2016). Examples of such nets are the MOCNESS (Multiple Opening Closing Net Environmental Sensing System) and the MultiNet ${ }^{\circledR}$, the latter being available especially for vertical tows (Christiansen, 2016).

To assess fish diversity, the same methods are used by the fishing industry, normally with a variety of nets. Trawling involves pulling a net through the water column or along the ocean floor. Bottom trawls are often the cause of major destruction of the seafloor, and are commonly used in fisheries, targeting slow-growing demersal fish species such as the orange roughy (Hoplostethus atlanticus) on seamounts (Clark, 1999; Clark et al., 2016). In addition, midwater trawls are frequently used to catch pelagic fish and cephalopods in the water column. If predatory fishes are the main subject of a study, long lines are a reliable method to assess the diversity and fish stocks in a certain habitat (Menezes and Sigler, 2016). They are generally baited, which results in scavengers and predatory species being the main catch. However, they are useful in areas where other sampling methods are inaccessible due to the bottom topography (Menezes and Sigler, 2016).

Sledges and dredges are designed to sample benthic organisms along the ocean floor (Gage, 1975; Kaiser and Brenke, 2016) using nets dragged along the sea floor. Unfortunately, quantitative sampling of the deep sea is not always possible, for example at hydrothermal vents, structures are very fragile and blind 


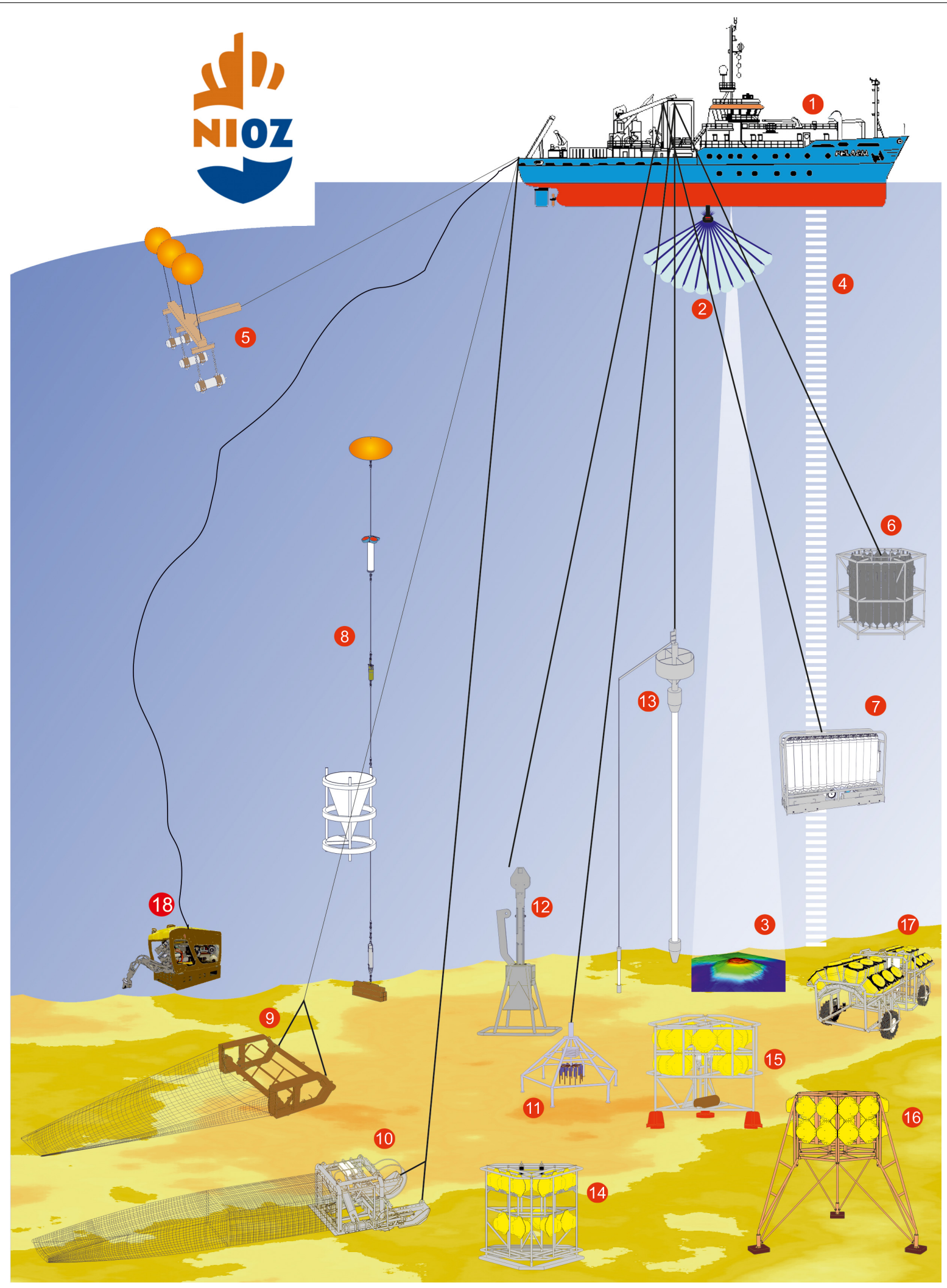

FIGURE 3 | Current technology used to sample the deep sea from the Dutch RV Pelagia (1). Especially useful for biodiversity research are CTDs with Niskin bottles to collect water samples (6 and 7), trawls and dredges (9 and 10), multi- and boxcorers (11 and 12), landers (14-16), and the Remotely Operated Vehicle (18) (reproduced with permission from the Royal Netherlands Institute for Sea Research NIOZ). 
sampling techniques cannot be used. Box corers are used to quantitatively collect benthic and sub-surface layers by lifting sediments up from the seafloor without disturbing the composition and layers (Narayanaswamy et al., 2016). Grabs, on the other hand, are semi-quantitative and only reach about $20 \mathrm{~cm}$ into the substrate (Narayanaswamy et al., 2016).

In the last few decades, modern technologies have improved our understanding of the deep sea immensely. The aforementioned equipment is often used in combination with video or camera systems, while sensors (e.g., CTDs) can simultaneously assess hydrological parameters.

Towed cameras and Autonomous Underwater Vehicles (AUVs) can capture habitat diversity on transects, and technology is improving continuously to ensure best identification based on high definition video systems (Bowden and Jones, 2016). Tools such as the Underwater Video Profiler (UVP) can be used to assess biodiversity, a device that specifically records the surroundings using a light source and high-resolution cameras. The resulting images are later analyzed, grouping the organisms observed into taxa (Stemmann et al., 2008). Even small phytoplankton specimens can be counted using a UVP system. These camera systems may not be representative of the actual fauna in the area, since the effects of light (red or white) are thought to attract certain species and confuse others who flee (Jamieson, 2016). In addition, for most taxa it is not possible to identify organisms to the species level based on images alone, therefore underrepresenting the effective species diversity.

Landers are long-term pre-programmed sampling devices to study the ocean floor; they are deployed and remain in the deep sea for months, autonomously sampling their surroundings in a multitude of ways (Pfannkuche and Linke, 2003). For example, bait can be used to attract local fauna, mimicking natural processes such as whale falls, and time-lapse or video imaging is used to detect species while simultaneously measuring parameters such as pressure or temperature (Jamieson, 2016). At the end of the sampling period, a trigger is released, which causes the landers to change in buoyancy and float up to the surface. The research ships are then able to collect them and retrieve any biological materials captured.

The most sophisticated methods to sample deep-sea biodiversity are the Remotely Operated Vehicles (ROVs) and Human Occupied Vehicles (HOVs), which can actively interact with the environment and are flexible due to adaptive control by the researchers. ROVs can be manipulated from the ship while underwater, while HOVs are manned and the scientists operating the vehicle are able to direct sampling arms and openings for sample storage (Kelley et al., 2016). For instance, if there is an interest for a specific area or animal, it is possible to zoom in and focus on it and capture live images of the behavior and morphology of the organism. In addition, experts can use robotic arms to capture specimens and transfer them into sealable sampling containers, take quantitative sediment cores, or set up experiments. The obvious advantage of ROVs over HOVs is that there is no direct danger to scientists while controlling an ROV from the boat, while HOVs carry a small chance of failure, for example due to fires from the electrical equipment.
To study biodiversity on a species level, specimens are usually caught and processed in a lab setting. The exact identification of the different species requires morpho-taxonomic experts and is very time intensive. For many taxa, there is little up-to-date literature on the identification of different species, and especially with deep sea specimens, it is a daunting task to identify each individual correctly down to the species level. To aid these efforts, tissue samples are often taken that can solve mysteries using DNA analyses.

In addition to these methods, environmental DNA (eDNA) has the potential to uncover even more biodiversity in the deep sea than classical taxonomic methods. The theory behind eDNA is that small particles of DNA remain in the surrounding water when an organism passes by, which can be detected by modern genetic analyses. However, to determine which species are found there, a comprehensive database on the species diversity of a habitat has to exist, which, unfortunately, is lacking for the deep sea environment (Sinniger et al., 2016). However, data on species diversity, even if the particular species are unknown, can be highly beneficial for ecosystem assessment practices or conservation efforts.

The future of deep-sea sampling is certainly a hopeful one, and the advances of technology will lead not only to more long-term sampling methods, but also to more gentle, focused probing. Even today, the expertise of scientists around the world can be combined during deep-sea camera dives through video conferences and live streamed to the public simultaneously. This was unimaginable just a few years ago (Consalvey et al., 2016), and the technological advances in the next few decades will likely be of similar significance. An important aspect of this research is the sharing of information between scientists to facilitate new experiments and a cumulative approach to research the deep sea. Considering the size of the deep sea, it is immensely important to share data on every aspect that was sampled, to preserve the habitat and learn more about it on a global scale.

\section{CAUSES OF HIGH BIODIVERSITY IN THE DEEP SEA}

In the most common environment in the deep sea, the abyssal plains, biodiversity is high, while productivity and biomass are low (Boucher and Lambshead, 2003; Glover and Smith, 2003). The reasons for such high biodiversity in the deep sea are a highly discussed topic (e.g., Danovaro et al., 2010), and since the habitat is far from uniform and covers over $50 \%$ of the surface of the planet, it is not possible to answer this using only one approach. A multitude of hypotheses exist and some of the more interesting ones will be discussed here. There are many potential parameters that may contribute significantly to the species diversity found in the deep sea, such as time, stable environmental conditions, or changing nutrient supply. It is also important to note that while biodiversity is indeed high overall, this is not true for all phyla and should be considered individually for different groups of organisms. Annelids and arthropods, as well as mollusks, seem to show disproportionally high biodiversity in the deep sea while megafauna groups such as chordates 
are less likely to follow a trend toward higher biodiversity (Morrissey and Sumich, 2012; McClain and Schlacher, 2015). In general, lower species diversity in the deep sea is found when conditions are suboptimal, such as low oxygen zones, strong currents, mudslides in deep sea trenches, or hydrothermal vent disturbances (Grassle et al., 1990).

Previously, the deep sea was considered a very homogenous and predictable environment, which caused Sanders to hypothesize in 1968 that the environmental stability would cause specialization due to high competition for the same resources and strong niche partitioning (Sanders, 1968; McClain and Schlacher, 2015). This time-stability hypothesis explains the high biodiversity through extreme specialization over large timescales. McClain and Schlacher (2015) note, however, that it is extremely difficult to prove competition between species in the deep sea. The time-stability hypothesis has now been abandoned, due to an increased understanding of the dynamics and heterogeneity of the deep ocean floor (Levin and Sibuet, 2011).

Since Sander's hypothesis, we have learned that the deepsea floor is very dynamic and there are pronounced differences between environments, even seasonal changes occur similarly to the surface waters. This suggests that biodiversity is caused by other factors, including small-scale variation of environmental characters, such as the foraging behavior of megafauna, woodand whale-falls, or uneven sediment area due to burrows or trails formed by migrating organisms (Rex and Etter, 2010).

Croppers, animals that prey on both living and dead organic matter, were also hypothesized to have an influence on the high diversity-since food is sparse in the deep sea, these animals are opportunistic feeders and may level the field for any competition between smaller, deposit-feeding species (Dayton and Hessler, 1972). Animals such as holothurians or asteroids potentially exhibit top-down control and limit competitive exclusion in other species (McClain and Schlacher, 2015). This is, again, difficult to prove, and exclusion experiments have yielded unclear results as to how diversity changes upon elimination of predators (McClain and Schlacher, 2015). Physical changes in the deep sea, such as anthropogenic disturbances from dredges, can have lasting effects on the environment. Depending on the structure of the sediment, disturbances may vanish within the shortterm, but an experiment in the Pacific on manganese nodule mining determined that the tracks of the dredging machines were very well preserved 26 years after the initial disturbance (Khripounoff et al., 2006). Events such as whale falls or the arrival of spring-bloom-detritus can have effects (such as community response or patch dynamics) over large timespans, and in the case of larger arrivals, decades (Smith and Baco, 2003). In 2002, large numbers of dead jellyfish were found between 300 and $3,300 \mathrm{~m}$ in the Arabian sea, slowly descending down the continental slope. This is possibly a great food source for deep sea life, and as jelly fish blooms are becoming increasingly more common, further investigation of the impact of blooms on the deep sea in the near future is needed (Brotz et al., 2012). These extraordinary events may shift the conditions in the deep sea for many years to come, such as increases in species density when environmental conditions become more favorable (Billett et al., 2010).
Another cause for high biodiversity could be the level of disturbance an ecosystem is subjected to. In the deep sea, large disturbances are rare but can wipe out large areas, for example through earthquakes, mudslides, or changes in ocean chemistry (McClain and Schlacher, 2015). The effects of such disturbance events are expected to have serious consequences for the species abundance and composition in the deep sea for potentially hundreds of years, and recolonization may be slow (Young and Richardson, 1998). Under those circumstances, opportunistic species may be able to dominate and recolonize an area faster than their competitors (Thiel, 1992). While this process may lead to a more homogenic community composition in the disturbed regions, overall biodiversity may be increased due to large regional differences.

The patch-mosaic hypothesis describes how ecosystems in the deep sea are a collection of microhabitats that animals are specifically adapted to, which in turn may create high species diversity (Gallucci et al., 2008). In some instances, this can mean that the organisms are themselves the ecosystem engineers and produce their own burrows and hard structures, such as on coldwater coral mounds. In addition, small differences in the deep sea habitat can foster larger differences in species assemblages (McClain and Schlacher, 2015). This hypothesis is very difficult to disprove, since very little of the seafloor has been sampled and it is difficult to detect ecosystem differences on small scales. However, Vanreusel et al. (2010) were able to use nematodes as a model phylum to show that globally, habitat heterogeneity does significantly contribute to biodiversity. Some genera were found particularly in certain habitats, suggesting strong adaptation to the challenging conditions such as biochemical gradients or high substrate complexity. The additive effects of small-scale heterogeneity, such as whale falls, and large-scale heterogeneity, such as seamounts of vent fields, likely contribute to a highly diverse fauna in the deep sea.

While sediment heterogeneity and specialization due to patch dynamics (caused by phytodetritus covering the seafloor in patches) certainly affects biodiversity, recent research has also pointed toward factors such as resource stability throughout the year (Corliss et al., 2009). Evidently, there is seasonality in the arrival of detritus from the surface-at higher latitudes, there are episodic flux events that bring relatively large amounts of resources to the deep sea (Billett et al., 1983). In lower latitudes, there is a more constant flux that coincides with the steady temperature and low primary production on the surface (Corliss et al., 2009). This was previously investigated by Lampitt and Antia (1997), who found the highest stability of particle flux to the deep sea in the tropics, with a decline toward the poles. Overall, in areas where organic carbon is supplied periodically and seasonality is present, opportunistic species can grow rapidly, reproduce and dominate in their habitat, which results in a lower diversity. In contrast, in tropical regions where seasonality is absent and organic carbon is supplied steadily, habitats are more diverse, with a more even distribution of species (Corliss et al., 2009). Danovaro et al. (2004) found that even slight shifts in temperature can significantly alter deep-sea biodiversity, which could have dramatic consequences as climate change is shifting ocean temperatures. A $0.4^{\circ} \mathrm{C}$ decrease in temperature was shown 
to have impacted nematode communities in two ways: an increase in biodiversity, with a decrease in abundance (Danovaro et al., 2004). Levitus et al. (2012) found that between 1955 and 2010, the heat content of the World Ocean between 0 and 2,000 m depth increased by $0.09^{\circ} \mathrm{C}$, with the first $700 \mathrm{~m}$ showing a mean warming of $0.18^{\circ} \mathrm{C}$. While changes in temperature in the deep sea occur slowly, even gradual warming would likely impact biodiversity negatively.

In abyssal plains, there are no obvious dispersal barriers and conditions are relatively constant. How gene flow is facilitated in the deep sea remains challenging for many taxa (Thomson et al., 2003), and little is known about larval dispersal. Most animals found in the deep sea possess a pelagic larval stage, which aids in exchanging genetic material between populations and furthers genetic drift. In species with lower larval dispersal capacity, specialization and speciation are likely drivers of biodiversity (Danovaro et al., 2017). Other taxa, for example nematodes, lack this larval stage and dispersal may occur much slower (Danovaro et al., 2017). OMZs may act as a dispersal barrier (Rogers, 2000), aiding allopatric speciation. However, in ecosystems where the habitat demands high adaptation to challenging conditions, such as hydrothermal vents, larval dispersal capacity is often found to be high, whereas distribution can be locally restricted (Shank and Halanych, 2007). Potential factors that must be considered when examining gene flow in the deep sea are the large population sizes of many taxa, as well as the absence of typical processes that reduce genetic diversity in shallow waters, such as bottlenecks due to changing environmental conditions (Etter et al., 2005).

How is there such high biodiversity in the deep sea? Many hypotheses have been proposed to answer this question, and the truth is likely a combination of many factors and hypotheseshowever, it is worth considering the immense area of the deep sea and the environmental differences that shape this habitat. Especially interesting for future research are changes in nutrient supply and how this varies within small areas. McClain and Schlacher (2015) note that while there are many hypotheses on why species diversity is high in the deep sea, it is now possible through genetic analyses to confirm or reject hypotheses such as the time-stability hypothesis proposed in the 1960s. This can also enable research on the colonization of the deep sea and whether a species originated from the deep oceanfor example, deep-sea Asellota isopods were found to have colonized the deep sea multiple times from the shallow waters (Raupach et al., 2004, 2012).

\section{THREATS TO BIODIVERSITY IN THE DEEP SEA}

There are two general areas of concern for the deep sea, namely the indirect effects of anthropogenic climate change, such as changes in ocean currents, ocean acidification, and warming, as well as direct human impacts, such as higher fishing intensity, oil and gas drilling, and deep-sea mining (Glover and Smith, 2003).

Brito-Morales et al. (2020) found that deep-sea ecosystems are especially at risk of climate-change-related species range shifts, challenging the common perception that the deep sea is slower to respond to climate change threats. This is not the case; for example, OMZs are a direct effect of climate change, as less oxygen can be dissolved in warmer water. Unfortunately, ocean warming will cause these zones to expand and alter the environment for millions of species currently dependent on high oxygen concentrations (Stramma et al., 2008). For instance, cephalopod and crustacean larvae were found to lose $60-100 \%$ of their vision in low oxygen conditions which is catastrophic for their survival and consequently their reproduction in a later life stage (McCormick et al., 2019).

Currently highly reported issues the shallow waters are facing, such as plastic or noise pollution, are also evident in the deep sea. Obvious threats are planned construction projects, for instance pipelines, or the laying of cables that disturbs the benthic environment (Jobstvogt et al., 2014). Noise pollution can also cause problems, not just during the construction work, but also through sonar emitted by military ships-it can cause mammals to emerge from the deep in a panic, which can lead to decompression sickness and death (Jepson et al., 2003). Further studies on the effects of noise in the deep sea are needed to understand how it affects different groups of organisms living at great depths. Another obvious threat is fishing activity-bottom trawling is a common fishing method targeting demersal fishes that threatens marine biodiversity by changing the sediment topography, increasing sediment resuspension, and consequently changing nutrient composition (Pusceddu et al., 2014). In addition, removing large mobile predators from the seabed can cause shifts in predator-prey dynamics (Ashford et al., 2019).

Plastic pollution is, unfortunately, not exclusive to the ocean surface; most of the debris deposited in the ocean sinks (Kane and Clare, 2019). Microplastics have been found in the guts of amphipods in the hadal zone, and even in the deepest trench in the ocean, the Mariana trench, all studied amphipods had ingested microplastics (Jamieson et al., 2019). In addition, Choy et al. (2019) found that the concentration of microplastics in the water column, measured down to $1,000 \mathrm{~m}$, was highest between 200 and $600 \mathrm{~m}$. Mesopelagic lanternfishes were recently shown to have high levels of plastic ingestion and their diel migration is likely an important transport mechanism for the plastic particles into the deeper waters (Savoca et al., 2021). The ingestion of plastics has a host of negative effects that are likely to impede health of the individual animals, with incumbent effects on biodiversity (Browne et al., 2013; Deudero and Alomar, 2015; Fossi et al., 2018).

Fish stocks around the world are dwindling, and fisheries are reaching beyond to greater depths to maintain their yields. Morato et al. (2006) found that fisheries catches have increased in depth since the late 1960s, and Oceana reports that fisheries in Europe have recently expanded down to 1,500 m (Oceana, 2015; Figure 4A). Considering benthic fishes, the mean depth of fishing increased by $22 \mathrm{~m}$ every decade (Morato et al., 2006; see also Figure 4B). These trends are very concerning, considering the life history of many species found in the deep sea. Unfortunately, deep-sea fishes are often slow in growth, longlived, and frequently have a k-strategy with low fecundity (Clark, 2001; D'onghia et al., 2009). Initially, deep-sea fishes can yield high catches and sustain fisheries, but they are depleted quickly 


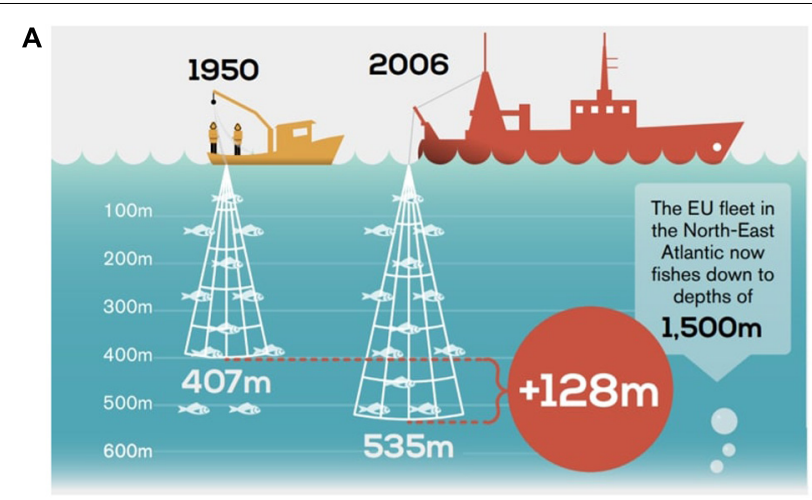

B

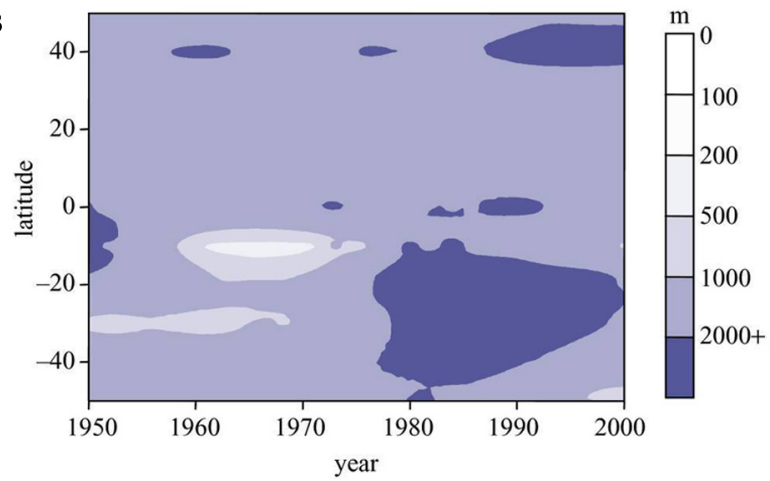

FIGURE 4 | (A) In Europe, fisheries are expanding to deeper depths down to $1,500 \mathrm{~m}$ in recent decades (reproduced from Oceana 2015, with permission from the authors). (B) Mean depth of global fisheries landings in the second half of the 20th century, shown in the different latitudes (reproduced from Pauly et al., 2005, with permission from the authors).

due to the life history of the fishes (Clark, 2001). For example, orange roughy (Hoplostethus atlanticus) yield was very high in the 90s in New Zealand, followed by a very rapid decline that is still ongoing (Clark, 2001; Clark et al., 2015). At the moment, deep-sea fisheries are not researched enough and based on the existing data, the situation is dire with fish stocks declining quickly (Devine et al., 2006).

Deep-sea mining is generally described as the extraction of valuable materials, such as gold, copper, or zinc, from different sources in the deep sea-most notably hydrothermal vents which have high concentrations of valuable minerals, and socalled manganese nodules (Folkersen et al., 2019). Technology is advancing fast in this field, and exploration licenses for mineral mining are currently used to research the potential of the deposits for human exploitation. In the Pacific, the Clarion-Clipperton Zone (CCZ) is an area managed by the International Seabed Authority, which has devised different areas of interest and given out licenses to research them to different stakeholders (Amon et al., 2016). These exploration areas have a high abundance of polymetallic nodules. There is mounting evidence that the hard structures the potentially mineable minerals provide are an important ecological asset, providing a stable ground for foundation species to establish (Vanreusel et al., 2016). Sponges and similar organisms can grow on nodules and provide a nursery for the eggs of many species. For example, megafauna, such as deep-sea incirrate octopods, depend on the hard substrate provided by manganese nodules to lay eggs, as they deposit their eggs on dead sponge stalks that grow on manganese nodules (Purser et al., 2016). In the case of polymetallic nodules, current knowledge is that they take millennia to develop and recovery of such ecosystems would, therefore, be unattainable in measurable time scales (Amon et al., 2016). Gollner et al. (2017) predicted altered community structure at mined areas for decades after the initial disturbance.

The heavy machinery used to retrieve the metals would suspend large amounts of sediment, causing plumes to form that can impact benthic biodiversity immensely (Jones et al., 2017). Deep-sea mining will expose organisms to potentially toxic substances with poorly understood reactions in the deepsea conditions (Mestre et al., 2014). It is impossible to gauge the potentially sublethal effects of the mix of toxic metals that would arise from mining plumes on the fauna in the deep sea (Hauton et al., 2017). Drazen et al. (2020) argue that while the benthic environment has been considered when evaluating the effects of deep-sea mining, ecological effects on pelagic ecosystems are understudied and must be considered as well. Other direct and indirect effects of mining in the deep sea are summed up in Table 1.

Since the deep sea has only been surveyed for a few decades, it is impossible to reconstruct how it has already changed due to anthropogenic impacts. For instance, whale falls are hypothesized to be important stepping stones for deep-sea species, both evolutionary and to aid dispersal, and are simply whale carcasses that sink to the ocean floor that are visited by a host of different species that slowly decompose the animal (National Research Council, 1995). Since whales have been heavily hunted throughout human history, it is unknown how the decline of cetacean population numbers has affected the deep sea (Butman et al., 1995). This is an obvious example for how difficult it is to obtain baseline data for the deep-sea environment, when it is unclear how much humans have already altered a habitat.

The largest threat to the deep sea is, unfortunately, human ignorance-public interest is already lacking for visible, abovesea-level environments where human impact is obvious, so there is little hope that the value of the deep sea will become a public issue (Jobstvogt et al., 2014). However, measuring the value of ecosystem services provided by the deep sea and

TABLE 1 | Direct and indirect threats due to deep-sea mining as described in Niner et al. (2018).

\begin{tabular}{ll}
\hline Direct threats & Indirect threats \\
\hline Removal of substrate and death of & Light, noise and electromagnetic \\
associated animals & pollution \\
Habitat loss and fragmentation & Reduction in biomass \\
Altered sediment composition and & Smothering of habitat and feeding \\
geomorphology & apparatuses of organisms \\
& Toxic and nutrient-rich plumes
\end{tabular}


making it conceivable by putting a monetary value to it might increase awareness.

Preserving the biodiversity of the deep sea may not be of the highest priority to policy makers and the general public but this is a dangerous gamble. Very little is known about the ecosystem, such as its key species, which species rely on each other, and any rare species responsible in maintaining the habitat (Herring, 2002). Hence, we cannot make reliable estimates of our impact and the implications of human disturbance.

\section{STRATEGIES TO AVOID LOSS OF BIODIVERSITY AND OUTLOOK}

As humans have a direct impact on the deep sea, a thorough inspection of the implications for the environment must be made. As in all other environments, there is a mitigation hierarchy to consider when planning any project that has an impact on any environment as established first for the US wetlands mitigation framework (McKenney and Kiesecker, 2010). It applies equally to the deep sea and is even more difficult to reach there since so little is known about the environmental variables. The first consideration must always be avoidance. It is important to note that the Nature 2000 already made clear that economic advantages should never come before ecological considerations, which applies heavily to deepsea mining (European Commission, 2000). If the advantages outweigh the environmental impact, the second step in the hierarchy must be applied: minimizing the impact (McKenney and Kiesecker, 2010). In the deep-sea environment, examples for minimizing are to reduce sediment plumes resulting from heavy machinery used on the ocean floor (Niner et al., 2018). Unfortunately, in the context of deep-sea mining, current technology is unable to protect biodiversity, which renders the minimization objective useless (Niner et al., 2018). The last resort of the hierarchy is remediation, or offsetting the damage done to outbalance the negative effects. This would encompass attempts to restore the natural biodiversity in the habitat by recolonizing it with larvae from similar environments, or providing a substrate suitable for the naturally occurring organisms to attach after removing the natural hard substrate (e.g., manganese nodules) (Niner et al., 2018). However, in the deep-sea context, it remains to be seen if remediation is possible, and we are not able to say with confidence what a good remediation project looks like in the deep sea.

While the deep sea might seem like an extreme environment to us, life is highly adapted to this environment just as it is in dark caves, deserts, and on high mountain ranges. More and more evidence is emerging that our expectations for the extreme nature of the organisms there is really exaggerated, and the ecological concepts we know from other ecosystems also apply (McClain et al., 2012). This may help us decide how to mitigate effects such as ocean temperature or acidity changes.

Unfortunately, it is difficult to gain traction when discussing why biodiversity in the deep sea is important, as it seems far removed to our daily lives. This is a misconception; the deep sea does offer goods and services whose loss would impact our daily lives. For example, the deep sea is an important carbon sink and provides us with resources such as fish, oil, or gas (Armstrong et al., 2012). The deep sea is not only an important player in climate change mitigation, it also has the potential to provide us with important pharmaceutical compounds and cycle nutrients that make life on Earth possible (Figure 5).

In general, the same problems occur in the deep sea that are worrisome in the shallow oceans as well, including the effects of climate change on the biodiversity of the habitat. Humans are already exploiting deep-sea fish stocks and are planning to exploit other deep-sea resources in the near future for material needs. This will without a doubt have lasting effects on the affected ecosystems, which should in itself be a serious deterrent for humans. While this may not be enough, research into the effects of the entire ocean ecosystem has to be stimulated, to highlight the importance of the deep sea as a habitat and an environment worth preserving.

With regards to deep-sea mining, it is still possible to halt large-scale exploitation of the ocean floor, however, if any metals are mined, it is critical to guarantee that they are used responsibly. With an expected increase in renewable energy usage around the globe, we need to be aware that these technologies rely heavily on metals (Kleijn et al., 2011). Consequently, we need to assure that any mined metals are used for such technologies, decreasing our carbon footprint overall and fighting climate change. In addition, no-take zones need to be established that are close-by and where biodiversity is similar to the mined areas-this is instrumental in aiding recovery through recolonization and increasing resilience of the habitat (Jones et al., 2018).

While there are many publications highlighting the threats of deep-sea mining and how this may affect biodiversity, few studies aim to illuminate the effects of fishing on the deep sea. Gauging resilience in a habitat such as the deep sea is difficult, since long-term studies are expensive and experiments showing the influence of deep-sea mining are scarce and in no relation to large-scale mining operations planned in the future. Gollner et al. (2017) found large variations in recovery depending on phyla and a potentially permanent shift in community structure based on

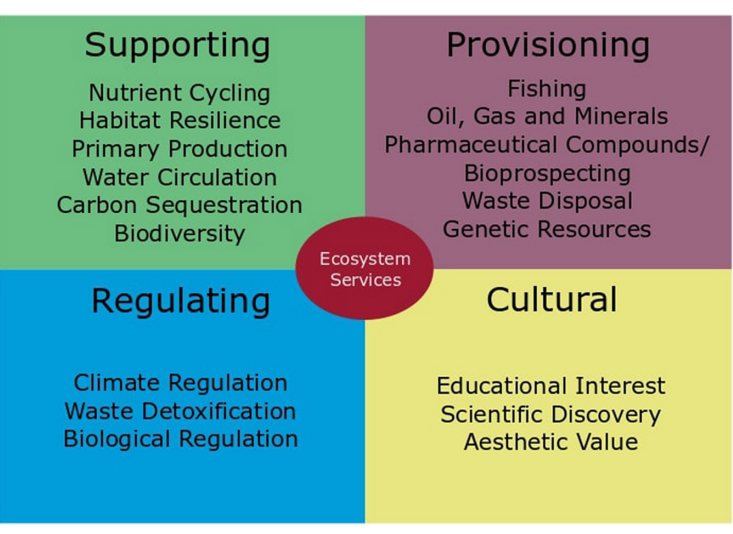

FIGURE 5 | Ecosystem services of the deep sea as discussed in Armstrong et al. (2012) and UNEP (2007). 
a review of literature focused on disturbance events related to deep-sea mining. Current research on artificial nodules deployed in the CCZ will determine whether colonization of artificial substrates is possible and within a reasonable timeframe (De Stigter et al., 2019). We have only just begun researching the deep sea, and long-term studies are desperately needed to truly understand resilience and recovery rates from disturbances.

There are many knowledge gaps about the deep-sea environment, but we can say one thing for sure-we are currently

\section{REFERENCES}

Amon, D. J., Ziegler, A. F., Dahlgren, T. G., Glover, A. G., Goineau, A., Gooday, A. J., et al. (2016). Insights into the abundance and diversity of abyssal megafauna in a polymetallic-nodule region in the eastern Clarion-Clipperton Zone. Sci. Rep. 6:30492. doi: 10.1038/srep30492

Anderson, T. R., and Rice, T. (2006). Deserts on the sea floor: edward Forbes and his azoic hypothesis for a lifeless deep ocean. Endeavour 30, $131-137$.

Armstrong, C. W., Foley, N. S., Tinch, R., and van den Hove, S. (2012). Services from the deep: steps towards valuation of deep sea goods and services. Ecosyst. Serv. 2, 2-13.

Ashford, O. S., Kenny, A. J., Barrio Froján, C. R. S., Horton, T., and Rogers, A. D. (2019). Investigating the environmental drivers of deep-seafloor biodiversity: a case study of peracarid crustacean assemblages in the Northwest Atlantic Ocean. Ecol. Evol. 9, 14167-14204. doi: 10.1002/ece3.5852

Baillon, S., Hamel, J. F., Wareham, V. E., and Mercier, A. (2012). Deep coldwater corals as nurseries for fish larvae. Front. Ecol. Environ. 10:351-356. doi: $10.1890 / 120022$

Bebber, D. P., Marriott, F. H. C., Gaston, K. J., Harris, S. A., and Scotland, R. W. (2007). Predicting unknown species numbers using discovery curves. Proc. $R$. Soc. B Biol. Sci. 274, 1651-1658. doi: 10.1098/rspb.2007.0464

Billett, D. S. M., Bett, B. J., Reid, W. D. K., and Smith, K. L. (2010). Long-term change in the abyssal NE Atlantic: the "Amperima Event" revisited. Deep Sea Res. Pt II 57, 1406-1417. doi: 10.1016/j.dsr2.2009.02.001

Billett, D. S. M., Lampitt, R. S., Rice, A. L., and Mantoura, R. F. C. (1983). Seasonal sedimentation of phytoplankton to the deep-sea benthos. Nature 302, 520-522. doi: $10.1038 / 302520 \mathrm{a} 0$

Bodil, B. A., Ambrose, W. G., Bergmann, M., Clough, L. M., Gebruk, A. V., Hasemann, C., et al. (2011). Diversity of the arctic deep-sea benthos. Mar. Biodivers. 41, 87-107. doi: 10.1007/s12526-010-0078-4

Boehlert, G. W., and Genin, A. (2013). A review of the effects of seamounts on biological processes. Geophys. Monogr. 43, 319-334.

Boucher, G., and Lambshead, P. J. D. (2003). Ecological biodiversity of marine nematodes in samples from temperate, tropical, and deep-sea regions. Conserv. Biol. 9, 1594-1604. doi: 10.1046/j.1523-1739.1995.09061594.x

Bowden, D. A., and Jones, D. O. B. (2016). “Towed cameras," in Biological Sampling in the Deep Sea, eds M. R. Clark, M. Consalvey, and A. A. Rowden (Chichester: Wiley-Blackwell), 260-284.

Brito-Morales, I., Schoeman, D. S., Molinos, J. G., Burrows, M. T., Klein, C. J., Arafeh-Dalmau, N., et al. (2020). Climate velocity reveals increasing exposure of deep-ocean biodiversity to future warming. Nat. Clim. Chang. 10, 576-581. doi: 10.1038/s41558-020-0773-5

Brondizio, E. S., Settele, J., Díaz, S., and Ngo, H. T. (2019). “Global assessment report on biodiversity and ecosystem services of the intergovernmental sciencepolicy platform on biodiversity and ecosystem services," in IPBES Secretariat, Bonn.

Brotz, L., Cheung, W. W. L., Kleisner, K., Pakhomov, E., and Pauly, D. (2012). Increasing jellyfish populations: trends in large marine ecosystems. Hydrobiologia 690, 3-20. doi: 10.1007/s10750-012-1039-7

Brown, A., and Thatje, S. (2014). Explaining bathymetric diversity patterns in marine benthic invertebrates and demersal fishes: physiological contributions to adaptation of life at depth. Biol. Rev. 89, 406-426. doi: 10.1111/brv.12061

Browne, M. A., Niven, S. J., Galloway, T. S., Rowland, S. J., and Rowland, R. C. (2013). Microplastic moves pollutants and additives to worms, reducing damaging the delicate balance of the largest ecosystem on earth, with unknown implications for our own survival and other closely interwoven environments.

\section{AUTHOR CONTRIBUTIONS}

EP drafted and critically reviewed the article based on the comments and suggestions of two anonymous peer reviewers.

functions linked to health and biodiversity. Curr. Biol. 23, 2388-2392. doi: 10.1016/j.cub.2013.10.012

Burney, D. A., and Flannery, T. F. (2005). Fifty millennia of catastrophic extinctions after human contact. Trends Ecol. Evol. 20, 395-401.

Butman, C., Carlton, J. T., and Palumbi, S. R. (1995). Whaling effects on deep-sea biodiversity. Conserv. Biol. 9, 462-464. doi: 10.1046/j.1523-1739.1995.9020462. $\mathrm{x}$

Ceballos, G., Ehrlich, P. R., Barnosky, A. D., García, A., Pringle, R. M., Palme, T. M., et al. (2015). Accelerated modern human-induced species losses: entering the sixth mass extinction. Sci. Adv. 1:e1400253. doi: 10.1126/sciadv.1400253

Choy, C. A., Robison, B. H., Gagne, T. O., Erwin, B., Firl, E., Halden, R. U., et al. (2019). The vertical distribution and biological transport of marine microplastics across the epipelagic and mesopelagic water column. Sci. Rep. 9, 1-9. doi: 10.1038/s41598-019-44117-2

Christiansen, B. (2016). "Deep-sea zooplankton sampling," in Biological Sampling in the Deep sea, eds M. R. Clark, M. Consalvey, and A. A. Rowden (Chichester: Wiley-Blackwell), 103-125.

Clark, M. (1999). Fisheries for orange roughy (Hoplostethus atlanticus) on seamounts in New Zealand. Oceanol. Acta 22, 593-602.

Clark, M. (2001). Are deepwater fisheries sustainable? - The example of orange roughy (Hoplostethus atlanticus) in New Zealand. Fish Res. 51, 123-135.

Clark, M., Roux, M.-J., and Cryer, M. (2015). New Zealand Research Relevant to the Assessment of Stocks of Orange Roughy (Hoplostethus atlanticus). Wellington: South Pacific Regional Fisheries Management Organisation.

Clark, M. R., Bagley, N. W., and Harley, B. (2016). “Trawls," in Biological Sampling in the Deep Sea, eds M. R. Clark, M. Consalvey, and A. A. Rowden (Chichester: Wiley-Blackwell), 126-158.

Consalvey, M., Clark, M. R., and Rowden, A. A. (2016). "The future of biological sampling in the deep sea," in Biological Sampling in the Deep Sea, eds M. R. Clark, M. Consalvey, and A. A. Rowden (Chichester: Wiley-Blackwell), 431438.

Cooke, R. S. C., Eigenbrod, F., and Bates, A. (2019). Projected losses of global mammal and bird ecological strategies. Nat. Commun. 10:2279. doi: 10.1038/ s41467-019-10284-z

Corliss, B. H., Brown, C. W., Sun, X., and Showers, W. J. (2009). Deep-sea benthic diversity linked to seasonality of pelagic productivity. Deep Sea Res. Pt I 56, 835-841. doi: 10.1016/j.dsr.2008.12.009

Costello, M. J., and Breyer, S. (2017). Ocean depths: the mesopelagic and implications for global warming. Curr. Biol. 27, R36-R38.

Creasey, S. S., and Rogers, A. D. (2008). Population genetics of bathyal and abyssal organisms. Adv. Mar. Biol. 35, 1-151.

Danovaro, R., Company, J. B., Corinaldesi, C. D., Onghia, G., Galil, B., Gambi, C., et al. (2010). Deep-sea biodiversity in the mediterranean sea: the known, the unknown, and the unknowable. PLoS One 5:e11832. doi: 10.1371/journal.pone. 0011832

Danovaro, R., Corinaldesi, C., Dell'Anno, A., and Snelgrove, P. V. R. (2017). The deep-sea under global change. Curr. Biol. 27, R461-R465.

Danovaro, R., Dell'Anno, A., and Pusceddu, A. (2004). Biodiversity response to climate change in a warm deep sea. Ecol. Lett. 7, 821-828. doi: 10.1111/j.14610248.2004.00634.x

Dayton, P. K., and Hessler, R. R. (1972). Role of biological disturbance in maintaining diversity in the deep sea. Deep Res. Oceanogr. Abstr. 19, 199-208. doi: 10.1016/0011-7471(72)90031-9

De Stigter, H., Haalboom, S., and Gollner, S. (2019). NIOZ@SEA | Joining the MiningImpact2 expedition of RV Sonne. Avaliable at: https://www.nioz.nl/en/ 
blog/niozatsea-joining-the-miningimpact2-expedition-of-rv-sonne (accessed 15 July 2019).

Des Roches, S., Post, D. M., Turley, N. E., Bailey, J. K., Hendry, A. P., Kinnison, M. T., et al. (2018). The ecological importance of intraspecific variation. Nat. Ecol. Evol. 2, 57-64. doi: 10.1038/s41559-017-0402-5

Desbruyères, D., Segonzac, M., and Bright, M. (2006). Handbook of Deep-Sea Hydrothermal Vent Fauna. Linz: Biologiezentrum der Oberösterreichischen Landesmuseen.

Deudero, S., and Alomar, C. (2015). Mediterranean marine biodiversity under threat: reviewing influence of marine litter on species. Mar. Pollut. Bull. 98, 58-68. doi: 10.1016/j.marpolbul.2015.07.012

Devine, J. A., Baker, K. D., and Haedrich, R. L. (2006). Fisheries: deep-sea fishes qualify as endangered. Nature 439:29. doi: 10.1038/439029a

D'onghia, G., Tursi, A., Marano, C. A., and Clifford, C. H. (2009). Life history traits of Hoplostethus mediterraneus (Pisces: Beryciformes) from the northwestern ionian sea (Mediterranean Sea). J. Mar. Biol. Ass. U.K. 78, 321-339. doi: 10.1017/s002531540004011x

Drazen, J. C., Smith, C. R., Gjerde, K. M., Haddock, S. H. D., Carter, G. S., Choy, C. A., et al. (2020). Opinion: midwater ecosystems must be considered when evaluating environmental risks of deep-sea mining. Proc. Natl. Acad. Sci. U.S.A $117,17455-17460$.

Durden, J. M., Bett, B. J., Jones, D. O. B., Huvenne, V. A. I., and Ruhl, H. A. L. (2015). Abyssal hills - hidden source of increased habitat heterogeneity, benthic megafaunal biomass and diversity in the deep sea. Prog. Oceanogr. 137, 209-218. doi: 10.1016/j.pocean.2015.06.006

Etter, R. J., Rex, M. A., Chase, M. R., and Quattro, J. M. (2005). Population differentiation decreases with depth in deep-sea bivalves. Evolution 59, 14791491. doi: 10.1111/j.0014-3820.2005.tb01797.x

European Commission (2000). Managing Natura 2000 Sites - The Provisions of Article 6 of the 'Habitats' Directive 92/43/EEC. Brussels: European Commission.

Fisher, C., Montagna, P., and Sutton, T. (2016). How did the deepwater horizon oil spill impact deep-sea ecosystems? Oceanography 29, 182-195. doi: 10.5670/ oceanog.2016.82

Folkersen, M. V., Fleming, C. M., and Hasan, S. (2019). Depths of uncertainty for deep-sea policy and legislation. Glob. Environ. Chang. 54, 1-5.

Fossi, M. C., Pedà, C., Compa, M., Tsangaris, C., Alomar, C., Claro, F., et al. (2018). Bioindicators for monitoring marine litter ingestion and its impacts on Mediterranean biodiversity. Environ Pollut 237, 1023-1040.

Fujii, T., Kilgallen, N. M., Rowden, A. A., and Jamieson, A. J. (2013). Deep-sea amphipod community structure across abyssal to hadal depths in the peruchile and kermadec trenches. Mar. Ecol. Prog. Ser. 492, 125-138. doi: 10.3354/ meps 10489

Gage, J. D. (1975). A comparison of the deep-sea epibenthic sledge and anchor-box dredge samplers with the van Veen grab and hand coring by diver. Deep Res. Oceanogr. Abstr. 22, 693-702. doi: 10.1016/0011-7471(75)90008-X

Gage, J. D., and Tyler, P. A. (1992). Deep-Sea Biology: A Natural History of Organisms at the Deep-Sea Floor. Cambridge: Cambridge University Press.

Gallucci, F., Moens, T., Vanreusel, A., and Fonseca, G. (2008). Active colonisation of disturbed sediments by deep-sea nematodes: evidence for the patch mosaic model. Mar. Ecol. Prog. Ser. 367, 173-183. doi: 10.3354/meps07537

Gerringer, M. E., Linley, T. D., Jamieson, A. J., Goetze, E., and Drazen, J. C. (2017). Pseudoliparis swirei sp. nov.: a newly-discovered hadal snailfish (Scorpaeniformes: Liparidae) from the Mariana Trench. Zootaxa 4358, 161-177. doi: 10.11646/zootaxa.4358.1.7

Glover, A. G., and Smith, C. R. (2003). The deep-sea floor ecosystem: current status and prospects of anthropogenic change by the year 2025. Environ. Conserv. 30, 219-241.

Gollner, S., Govenar, B., Arbizu, P. M., Mills, S., Le Bris, N., and Weinbauer, M. (2015). Differences in recovery between deep-sea hydrothermal vent and vent-proximate communities after a volcanic eruption. Deep Sea Res. Pt I 106, 167-182. doi: 10.1016/j.dsr.2015.10.008

Gollner, S., Kaiser, S., Menzel, L., Jones, D. O. B., Brown, A., Mestre, N. C., et al. (2017). Resilience of benthic deep-sea fauna to mining activities. Mar. Environ. Res. 129, 76-101.

Gooday, A. J. (1988). A response by benthic Foraminifera to the deposition of phytodetritus in the deep sea. Nature 332, 70-73. doi: 10.1038/332070a0

Gooday, A. J., Bett, B. J., Escobar, E., Ingole, B., Levin, L. A., Neira, C., et al. (2010). Habitat heterogeneity and its influence on benthic biodiversity in oxygen minimum zones. Mar. Ecol. 31, 125-147. doi: 10.1111/j.1439-0485.2009. 00348.x

Gooday, A. J., Levin, L. A., Aranda da Silva, A., Bett, B. J., Cowie, G. L., Dissard, D., et al. (2009). Faunal responses to oxygen gradients on the Pakistan margin: a comparison of foraminiferans, macrofauna and megafauna. Deep Sea Res. Pt II 56, 488-502. doi: 10.1016/j.dsr2.2008.10.003

Grassle, F. J., Maciolek, N. J., and Blake, J. A. (1990). ") Are deep-sea communities resilient?," in The Earth in Transition: Patterns and Processes of Biotic Impoverishment, ed. G. M. Woodwell (Cambridge: Cambridge University Press), 385-393.

Gray, J. S. (1997). Marine biodiversity: patterns, threats and conservation needs. Biodivers. Conserv. 6, 153-175. doi: 10.1023/A:1018335901847

Gunderson, L. H. (2002). Ecological Resilience-In theory and application. Annu. Rev. Ecol. Syst. 31, 425-439. doi: 10.1146/annurev.ecolsys.31.1.425

Hauton, C., Brown, A., Thatje, S., Mestre, N. C., Bebianno, M. J., Martins, I., et al. (2017). Identifying toxic impacts of metals potentially released during deep-sea mining-a synthesis of the challenges to quantifying risk. Front. Mar. Sci. 4:368. doi: $10.3389 /$ fmars. 2017.00368

Herring, P. (2002). The Biology of the Deep Ocean. Oxford: Oxford University Press. Holling, C. S. (1996). "Engineering resilience versus ecological resilience," in Engineering Within Ecological Constraints, ed. P. Schulze (Washington DC: National Academy of Sciences).

Iken, K., Brey, T., Wand, U., Voigt, J., and Junghans, P. (2001). Food web structure of the benthic community at the Porcupine Abyssal Plain (NE Atlantic): A stable isotope analysis. Prog. Oceanogr. 50, 383-405.

Jamieson, A. J. (2016). “Landers: baited cameras and traps," in Biological Sampling in the Deep Sea, eds M. R. Clark, M. Consalvey, and A. A. Rowden (Chichester: Wiley-Blackwell), 228-259.

Jamieson, A. J., Brooks, L. S. R., Reid, W. D. K., Piertney, S. B., Narayanaswamy, B. E., Linley, T. D., et al. (2019). Microplastics and synthetic particles ingested by deep-sea amphipods in six of the deepest marine ecosystems on Earth. R. Soc. Open Sci. 6:180667. doi: 10.1098/rsos.180667

Jamieson, A. J., Fujii, T., Mayor, D. J., Solan, M., and Priede, I. G. (2010). Hadal trenches: the ecology of the deepest places on Earth. Trends Ecol. Evol. 25, 190-197.

Jepson, P. D., Arbelo, M., Deaville, R., Patterson, I. A., Castro, P., Baker, J. R., et al. (2003). Gas-bubble lesions in stranded cetaceans. Nature 425, 575-576. doi: $10.1038 / 425575$ a

Jobstvogt, N., Hanley, N., Hynes, S., Kenter, J., and Witte, U. (2014). Twenty thousand sterling under the sea: Estimating the value of protecting deep-sea biodiversity. Ecol. Econ. 97, 10-19.

Jones, D. O. B., Ardron, J. A., Colaço, A., and Durden, J. M. (2018). Environmental considerations for impact and preservation reference zones for deep-sea polymetallic nodule mining. Mar. Policy 118:103312.

Jones, D. O. B., Kaiser, S., Sweetman, A. K., Smith, C. R., Menot, L., Vink, A., et al. (2017). Biological responses to disturbance from simulated deep-sea polymetallic nodule mining. PLoS One 12:e0171750. doi: 10.1371/journal.pone. 0171750

Kaiser, S., and Brenke, N. (2016). "Epibenthic sledges," in Biological Sampling in the Deep Sea, eds M. R. Clark, M. Consalvey, and A. A. Rowden (Chichester: Wiley-Blackwell), 184-206.

Kane, I. A., and Clare, M. A. (2019). Dispersion, accumulation, and the ultimate fate of microplastics in deep-marine environments: a review and future directions. Front. Earth Sci. 7:80. doi: 10.3389/feart.2019.00080

Kelley, C., Kerby, T., Sarradin, P.-M., Sarrazin, J., and Lindsay, D. J. (2016). "Submersibles and Remotely Operated Vehicles," in Biological Sampling in the Deep Sea, eds M. R. Clark, M. Consalvey, and A. A. Rowden (Chichester: Wiley-Blackwell), 285-305.

Kelley, D. S., Karson, J. A., Blackman, D. K., Früh-Green, G. L., Butterfield, D. A., Lilley, M. D., et al. (2001). An off-axis hydrothermal vent field near the mid-atlantic ridge at $30^{\circ} \mathrm{N}$. Nature 412, 145-149. doi: 10.1038/35084000

Kelley, D. S., Karson, J. A., Früh-Green, G. L., Yoerger, D. R., Shank, T. M., Butterfield, D. A., et al. (2005). A serpentinite-hosted ecosystem: the lost city hydrothermal field. Science 307, 1428-1434. doi: 10.1126/science.1102556

Khripounoff, A., Caprais, J. C., Crassous, P., and Etoubleau, J. (2006). Geochemical and biological recovery of the disturbed seafloor in polymetallic nodule fields of the Clipperton-Clarion Fracture Zone (CCFZ) at 5,000-m depth. Limnol. Oceanogr. 51, 2033-2041. doi: 10.4319/lo.2006.51.5.2033 
Kirkman, C. H., and Bitz, C. M. (2011). The effect of the sea ice freshwater flux on Southern Ocean temperatures in CCSM3: deep-ocean warming and delayed surface warming. J. Clim. 24, 2224-2237. doi: 10.1175/2010JCLI3625.1

Kleijn, R., van der Voet, E., Kramer, G. J., van Oers, L., and van der Giesen, C. (2011). Metal requirements of low-carbon power generation. Energy 36, 5640-5648. doi: 10.1016/j.energy.2011.07.003

Lacey, N. C., Rowden, A. A., Clark, M. R., Kilgallen, N. M., Linley, T., Mayor, D. J., et al. (2016). Community structure and diversity of scavenging amphipods from bathyal to hadal depths in three South Pacific Trenches. Deep Sea Res. Pt I 111, 121-137. doi: 10.1016/j.dsr.2016.02.014

Lambshead, P. J. D., Brown, C. J., Ferrero, T. J., Mitchell, N. J., Smith, C. R., Hawkins, L. E., et al. (2002). Latitudinal diversity patterns of deep-sea marine nematodes and organic fluxes: a test from the central equatorial pacific. Mar. Ecol. Prog. Ser. 236, 129-135. doi: 10.3354/meps236129

Lampitt, R. S. (1985). Evidence for the seasonal deposition of detritus to the deepsea floor and its subsequent resuspension. Deep Sea Res. Pt I 32, 885-897. doi: 10.1016/0198-0149(85)90034-2

Lampitt, R. S., and Antia, A. N. (1997). Particle flux in deep seas: regional characteristics and temporal variability. Deep Sea Res. Pt I 44, 1377-1403. doi: 10.1016/S0967-0637(97)00020-4

Lauerman, L. M. L., and Kaufmann, R. S. (1998). Deep-sea epibenthic echinoderms and a temporally varying food supply: results from a one year time series in the N.E. Pacific. Deep Sea Res. Pt II 45, 817-842. doi: 10.1016/S0967-0645(98) 00004-6

Levin, L. A., and Sibuet, M. (2011). Understanding continental margin biodiversity: a new imperative. Ann. Rev. Mar. Sci. 4, 79-112. doi: 10.1146/annurev-marine120709- 142714

Levin, L. A., Sibuet, M., Gooday, A. J., Smith, C. R., and Vanreusel, A. (2010). The roles of habitat heterogeneity in generating and maintaining biodiversity on continental margins: an introduction. Mar. Ecol. 31, 1-5. doi: 10.1111/j.14390485.2009.00358.x

Levitus, S., Antonov, J. I., Boyer, T. P. O. K., Baranova, H. E., Garcia, R. A., Locarnini, R. A., et al. (2012). World ocean heat content and thermosteric sea level change (0-2000m), 1955-2010. Geophys. Res. Lett. 39:L10603. doi: 10.1029/ 2012GL051106

Lyons, S. K., Smith, F. A., and Brown, J. H. (2004). Of mice, mastodons and men: human-mediated extinctions on four continents. Evol. Ecol. Res. 6, 339-358.

McClain, C. R., Allen, A. P., Tittensor, D. P., and Rex, M. A. (2012). Energetics of life on the deep seafloor. Proc. Natl. Acad. Sci. U.S.A. 109, 15366-15371. doi: $10.1073 /$ pnas.1208976109

McClain, C. R., and Schlacher, T. A. (2015). On some hypotheses of diversity of animal life at great depths on the sea floor. Mar. Ecol. 36, 849-872. doi: $10.1111 /$ maec. 12288

McCormick, L. R., Levin, L. A., and Oesch, N. W. (2019). Vision is highly sensitive to oxygen availability in marine invertebrate larvae. J. Exp. Biol. 222:jeb200899. doi: $10.1242 / \mathrm{jeb} .200899$

McKenney, B. A., and Kiesecker, J. M. (2010). Policy development for biodiversity offsets: a review of offset frameworks. Environ. Manag. 45, 165-176.

Menezes, G. M., and Sigler, M. F. (2016). "Longlines," in Biological Sampling in the Deep Sea, eds M. R. Clark, M. Consalvey, and A. A. Rowden (Chichester: Wiley-Blackwell), 159-183.

Mestre, N. C., Calado, R., and Soares, A. M. V. M. (2014). Exploitation of deep-sea resources: the urgent need to understand the role of high pressure in the toxicity of chemical pollutants to deep-sea organisms. Environ. Pollut. 185, 369-371. doi: 10.1016/j.envpol.2013.10.021

Mora, C., Tittensor, D. P., Adl, S., Simpson, A. G., and Worm, B. (2011). How many species are there on earth and in the ocean? PLoS Biol. 9:e1001127. doi: 10.1371/journal.pbio.1001127

Mora, C., Tittensor, D. P., and Myers, R. A. (2008). The completeness of taxonomic inventories for describing the global diversity and distribution of marine fishes. Proc. R. Soc. B Biol. Sci. 275, 149-155. doi: 10.1098/rspb.2007.1315

Morato, T., Hoyle, S. D., Allain, V., and Nicol, S. J. (2010). Seamounts are hotspots of pelagic biodiversity in the open ocean. Proc. Natl. Acad. Sci. U.S.A. 107, 9707-9711. doi: 10.1073/pnas.0910290107

Morato, T., Watson, R., Pitcher, T. J., and Pauly, D. (2006). Fishing down the deep. Fish Fish. 7, 24-34. doi: 10.1111/j.1467-2979.2006.00205.x

Morrissey, J. F., and Sumich, J. L. (2012). Biology of Marine Life. Sudbury, MA: Jones \& Bartlett Learning LLC.
Narayanaswamy, B. E., Bett, B. J., Lamont, P. A., Rowden, A. A., Bell, E. M., Menot, L., et al. (2016). "Corers and grabs," in Biological Sampling in the Deep sea, eds M. R. Clark, M. Consalvey, and A. A. Rowden (Chichester: Wiley-Blackwell), 207-227.

National Research Council (1995). Understanding Marine Biodiversity. Washington DC: The National Academies Press.

National Research Council (2013). An Ecosystem Services Approach to Assessing the Impacts of the Deepwater Horizon Oil Spill in the Gulf of Mexico. Washington DC: The National Academies Press.

Niner, H. J., Levin, L. A., Turner, P. J., Gianni, M., Jaeckel, A., Jones, D. O. B., et al. (2018). Deep-sea mining with no net loss of Biodiversity-An impossible aim. Front. Mar. Sci. 5:53. doi: 10.3389/fmars.2018.00053

Oceana (2015). Exploiting the Most Vulnerable Resources. url. Avaliable at: https://eu.oceana.org/en/publications/reports/exploiting-most-vulnerableresources (accessed August 15, 2019).

Oliver, T. H., Heard, M. S., Isaac, N. J. B., Roy, D. B., Procter, D., Eigenbrod, F., et al. (2015). Biodiversity and resilience of ecosystem functions. Trends Ecol. Evol. 30, 673-684.

Paulmier, A., and Ruiz-Pino, D. (2009). Oxygen minimum zones (OMZs) in the modern ocean. Prog. Oceanogr. 80, 113-128. doi: 10.1016/j.pocean.2008.08. 001

Pauly, D., Watson, R., and Alder, J. (2005). Global trends in world fisheries: impacts on marine ecosystems and food security. Philos. Trans. R. Soc. Lond. B Biol. Sci. 360, 5-12. doi: 10.1098/rstb.2004.1574

Pfannkuche, O., and Linke, P. (2003). GEOMAR landers as long-term deep-sea observatories. Sea Technol. 44, 50-55.

Pitcher, T. J., Morato, T., Hart, P. J. B., Clark, M. R., Haggan, N., Santos, R. S, et al. (2007). Seamounts: Ecology, Fisheries \& Conservation. Oxford: Blackwell Publishing.

Price, A. R. G. (2002). Simultaneous "hotspots" and "coldspots" of marine biodiversity and implications for global conservation. Mar. Ecol. Prog. Ser. 241, 23-27. doi: $10.3354 / \mathrm{meps} 241023$

Purser, A., Marcon, Y., Hoving, H. J. T., Vecchione, M., Piatkowski, U., Eason, D., et al. (2016). Association of deep-sea incirrate octopods with manganese crusts and nodule fields in the Pacific Ocean. Curr. Biol. 26, R1268-R1269.

Pusceddu, A., Bianchelli, S., Martín, J., Puig, P., Palanques, A., Masqué, P., et al. (2014). Chronic and intensive bottom trawling impairs deep-sea biodiversity and ecosystem functioning. Proc. Natl. Acad. Sci. U.S.A. 111, 8861-8866. doi: 10.1073/pnas.1405454111

Ramirez-Llodra, E., and Billet, D. S. M. (2006). "Deep-sea ecosystems: pristine biodiversity reservoir and technological challenges," in The Exploration of Marine Biodiversity: Scientific and Technological Challenges, ed. C. M. Duarte (Bilbao: Fundación BBVA), 63-92.

Ramirez-Llodra, E., Brandt, A., Danovaro, R., De Mol, D., Escobar, E., German, C. R., et al. (2010). Deep, diverse and definitely different: unique attributes of the world's largest ecosystem. Biogeosciences 7, 2851-2899. doi: 10.5194/bg-72851-2010

Raupach, M. J., Held, C., and Wägele, J. W. (2004). Multiple colonization of the deep sea by the Asellota (Crustacea: Peracarida: Isopoda). Deep Sea Res. Pt II 51, 1787-1795. doi: 10.1016/j.dsr2.2004.06.035

Raupach, M. J., Mayer, C., Malyutina, M., and Wägele, J. W. (2012). Multiple origins of deep-sea Asellota (Crustacea: Isopoda) from shallow waters revealed by molecular data. Proc. R. Soc. B Biol. Sci. 276, 799-808. doi: 10.1098/rspb.2008. 1063

Régnier, C., Achaz, G., Lambert, A., Cowie, R. H., Bouchet, P., Fontaine, B., et al. (2015). Mass extinction in poorly known taxa. Proc. Natl. Acad. Sci. U.S.A. 112, 7761-7766. doi: 10.1073/pnas.1502350112

Rex, M. A., and Etter, R. J. (2010). Deep-sea Biodiversity. Cambridge, MA: Harvard Univesity Press.

Robert, K., Jones, D. O. B., Georgiopoulou, A., and Huvenne, V. A. L. (2019). Cold-water coral assemblages on vertical walls from the Northeast Atlantic. Divers. Distrib. 26, 284-298. doi: 10.1111/ddi.13011

Roberts, C. M. (2002). Deep impact: the rising toll of fishing in the deep sea. Trends Ecol. Evol. 17, 242-245.

Roberts, J. M., Wheeler, A. J., and Freiwald, A. (2006). Reefs of the deep: the biology and geology of cold-water coral ecosystems. Science 312, 543-547. 
Rogers, A. D. (2000). The role of the oceanic oxygen minima in generating biodiversity in the deep sea. Deep Sea Res. Pt II 47, 119-148. doi: 10.1016/S09670645(99)00107-1

Sanders, H. L. (1968). Marine benthic diversity: a comparative study. Am. Nat. 102, 243-282. doi: 10.1086/282541

Sandom, C., Faurby, S., Sandel, B., and Svenning, J. C. (2014). Global late Quaternary megafauna extinctions linked to humans, not climate change. Proc. R. Soc. B Biol. Sci. 281, 20133254. doi: 10.1098/rspb.2013.3254

Savoca, M. S., McInturf, A. G., and Hazen, E. L. (2021). Plastic ingestion by marine fish is widespread and increasing. Glob. Change Biol. 50, 657-697. doi: $10.1111 /$ gcb.15533

Shank, T. M., and Halanych, K. M. (2007). Toward a mechanistic understanding of larval dispersal: Insights from genomic fingerprinting of the deep-sea hydrothermal vent tubeworm Riftia pachyptila. Mar. Ecol. 28, 25-35. doi: 10. 1111/j.1439-0485.2007.00146.x

Sinniger, F., Pawlowski, J., Harii, S., Gooday, A. J., Yamamoto, H., Chevaldonné, P., et al. (2016). Worldwide analysis of sedimentary DNA reveals major gaps in taxonomic knowledge of deep-sea benthos. Front. Mar. Sci. 3:92. doi: 10.3389/ fmars.2016.00092

Smith, C. R., and Baco, A. R. (2003). Ecology of whale falls at the deep-sea floor. Oceanogr. Mar. Biol. 41, 311-354.

Smith, C. R., De Leo, F. C., Bernardino, A. F., Sweetman, A. K., and Arbizu, P. M. (2008). Abyssal food limitation, ecosystem structure and climate change. Trends Ecol. Evol. 23, 518-528.

Smith, C. R., and Demopoulos, A. W. J. (2003). “The deep Pacific Ocean floor," in Ecosystems of the Deep Oceans, ed. P. A. Tyler (Amsterdam: Elsevier), 179-218.

Soetaert, K., Mohn, C., Rengstorf, A., Grehan, A., and van Oevelen, D. (2016). Ecosystem engineering creates a direct nutritional link between 600-m deep cold-water coral mounds and surface productivity. Sci. Rep. 6:35057. doi: 10 . 1038/srep35057

Stemmann, L., Hosia, A., Youngbluth, M. J., Picheral, M., and Gorsky, G. (2008). Vertical distribution $(0-1000 \mathrm{~m})$ of macrozooplankton, estimated using the Underwater Video Profiler, in different hydrographic regimes along the northern portion of the Mid-atlantic ridge. Deep Sea Res Pt II 55, 94-105. doi: 10.1016/j.dsr2.2007.09.019

Steneck, R. S., Graham, M. H., Bourque, B. J., Corbet, D., and Erlandson, J. M. (2002). Kelp forest ecosystems: biodiversity, stability, resilience and future. Environ. Conserv. 29, 436-459.

Stocks, K. I., and Hart, P. J. (2007). "Biogeography and biodiversity of seamounts," in Seamounts: Ecology, Fisheries, and Conservation, Vol. 12, eds T. J. Pitcher, T. Morato, P. J. B. Hart, M. R. Clark, N. Haggan, and R. S. Santos (Oxford: Blackwell), 255-281. doi: 10.1002/9780470691953.ch13 Blackwell Fisheries and Aquatic Resources Series.

Stramma, L., Johnson, G. C., Sprintall, J., and Mohrholz, V. (2008). Expanding oxygen-minimum zones in the tropical oceans. Science 320, 655-658. doi: 10. $1126 /$ science. 1153847
Thiel, H. (1992). Deep-sea environmental disturbance and recovery potential. Int. Rev. Hydrobiol. 77, 331-339. doi: 10.1002/iroh.19920770213

Thistle, D. (2003). "The deep-sea floor: an overview," in Ecosystems of the Deep Oceans, ed. P. A. Tyler (Amsterdam: Elsevier), 5-38.

Thomson, R. E., Mlhály, S. F., Rabinovich, A. B., McDuff, R. E., Veirs, S. R., Stahr, F. R., et al. (2003). Constrained circulation at endeavour ridge facilitates colonization by vent larvae. Nature 424, 545-549. doi: 10.1038/nature01 824

Turley, C. M., Roberts, J. M., and Guinotte, J. M. (2007). Corals in deep-water: will the unseen hand of ocean acidification destroy cold-water ecosystems? Coral Reefs 26, 445-448. doi: 10.1007/s00338-007-0247-5

UNEP (2007). Deep-Sea Biodiversity and Ecosystems: A Scoping Report on Their Socio-Economy, Management and Governance. Cambridge: UNEP World Conservation Monitoring Centre.

van Dover, C. L. (2000). The Ecology of Deep-Sea Hydrothermal Vents. Princeton, NJ: Princeton University Press.

Vanreusel, A., Fonseca, G., Danovaro, R., Cristina Da Silva, M., Esteves, A. M., Ferrero, T., et al. (2010). The contribution of deep-sea macrohabitat heterogeneity to global nematode diversity. Mar. Ecol. 31, 6-20. doi: 10.1111/ j.1439-0485.2009.00352.x

Vanreusel, A., Hilario, A., Ribeiro, P. A., Menot, L. M., and Arbizu, P. M. (2016). Threatened by mining, polymetallic nodules are required to preserve abyssal epifauna. Sci. Rep. 6:26808. doi: 10.1038/srep26 808

Yancey, P. H., Gerringer, M. E., Drazen, J. C., Rowden, R. R., and Jamieson, A. (2014). Marine fish may be biochemically constrained from inhabiting the deepest ocean depths. Proc. Natl. Acad. Sci. U.S.A. 111, 4461-4465. doi: 10.1073/ pnas.1322003111

Yesson, C., Clark, M. R., Taylor, M. L., and Rogers, A. D. (2011). The global distribution of seamounts based on 30 arc seconds bathymetry data. Deep Sea Res. Pt I 58, 442-453. doi: 10.1016/j.dsr.2011.02.004

Young, D. K., and Richardson, M. D. (1998). Effects of waste disposal on benthic faunal succession on the abyssal seafloor. J. Mar. Syst. 14, 319-336. doi: 10.1016/ S0924-7963(97)00033-X

Conflict of Interest: The author declares that the research was conducted in the absence of any commercial or financial relationships that could be construed as a potential conflict of interest.

Copyright (c) 2021 Paulus. This is an open-access article distributed under the terms of the Creative Commons Attribution License (CC BY). The use, distribution or reproduction in other forums is permitted, provided the original author(s) and the copyright owner(s) are credited and that the original publication in this journal is cited, in accordance with accepted academic practice. No use, distribution or reproduction is permitted which does not comply with these terms. 